\title{
MARINE BORERS RESISTANCE OF CHEMICALLY MODIFIED PORTUGUESE WOOD
}

\section{Duarte Barroso Lopes 1,2,^, Carsten $\mathrm{Mai}^{2}$, Holger Militz ${ }^{2}$}

\begin{abstract}
This study deals with the role of hardness and chemical toxicity in the resistance of pinewood to marine borers.

Portuguese wood Maritime pine (Pinus pinaster) was modified with 1,3-dimethylol 4,5-dihydroxy ethylene urea (DMDHEU), methylated methylol melamine (MMF), tetraethoxysilane (TEOS) and two types of wax. In addition, for comparative purposes, different control species, Ipê, Beech and Blue Gum and CCA treated pine were included.
\end{abstract}

All specimens were exposed over 2 years in sea (Porto, north of Portugal). Three inspections were performed after exposure (6,12 and 24 months). The influence of type and level of modification as well as hardness was evaluated.

As results: Specimens modified with resin have shown slight or trace attack by Teredinids in DMDHEU with low level of modification (10\% of weight percent gain, WPG); MMF resin with high and low level of modification ( $25 \%$ and $10 \%$ of WPG) have shown trace to moderate attack, respectively.

With the TEOS and wax impregnated wood which fill the cell lumens no significant difference in marine borers attack was found as compared to unmodified control specimens, despite the increased hardness.

Keywords: Chemical modification, resistance, EN 275, Limnorids, marine borers, Pinus pinaster, Teredinids, use class 5 .

\section{INTRODUCTION}

An adequate service life of wooden structures in the sea is ensured only: If wood is treated with biocide wood preservatives with high retention level or; If some tropical hardwoods, with known natural resistance, are used. However, the poor public image of use the tropical hardwoods, as contribution to deforestation at one hand and legal requirements to restrict the use of biocide preservatives, leaching and end disposal, on the other hand, leading to new demands with modified wood (Brelid et al. 2000, Borges and Cragg 2005, Westin et al. 2007, Kluppel et al. 2010, EN350-1, EN350-2, EN460).

Eaton and Hale (1983) have reviewed the resistance of wood in marine use. Methods for examining their performance in this environment are described in EN 275 (1992). Fougerousse (1971) and afterwards Eaton et al. (1989), they reported, in worldwide sites, the performance of tropical hardwood species in marine application.

\footnotetext{
${ }^{1}$ School of Engineering - Polytechnic of Porto, Rua Dr. António Bernardino de Almeida, n. ${ }^{\circ} 431$ zip code: 4200-072 Porto - Portugal

${ }^{2}$ Wood Biology and Wood Products, Büsgenweg 4 - 37077, Germany

^Corresponding author: dbl@isep.ipp.pt

Received: 02.11.2012. Accepted:16.06. 2013.
} 
Modified wood gave good performances in marine environment: Johnson and Rowell (1988) found high resistance at field trials, with propylene oxide, butylenes oxide and acetic anhydride (20\% WPG). Other authors tested different types of modified wood in hazard class 5, permanently wetted in seawater (EN 335-2) and the main conclusions were: furfurylation, acetylation, MMF and DMDHEU performed best and a minimum level of modification was needed (Brelid et al. 2000, Borges et al. 2005, Westin et al. 2006, Papadopoulos et al. 2008 and Klüppel et al. 2010).

For wood resistance, the assumption is that hardness, as an isolate variable, may also affect feeding and action of marine organisms, as has been shown for terrestrial wood-boring arthropods (Behr et al. 1972, Green et al. 2004, Morales-Ramos and Rojas 2005). Hardness of wood is an intrinsic feature and has a good correlation with different properties (Kollman and Cotê 1967, Machado et al. 2003, Li et al. 2008, Esteves et al. 2009). For this reason, hardness is an important factor of wood quality. In general, hardwood species (Ipê, eg.) has high natural resistance. However, two main variables are involved and tough to isolate: The amount of extractives and hardness. Cragg et al. (2007) have shown a significant correlation between micro hardness and Limnoria pellets productions in laboratory conditions. In the latter work, a large range of wood species led a densities range between 100 up to $1000 \mathrm{~kg} . \mathrm{m}^{-3}$. However, any consideration was not done about the role of the toxicity of the extractives (amounts and type) derived from different wood species.

Modified wood is a well-known method to increase hardness in various degrees: Acetylation, MMF, thermal modification in vegetable oil, furfurylation, maleoylation, succinylation, $\mathrm{N}$-methylol acrylamide, DMDHEU, TEOS and wax are some examples (Krause et al. 2003, Schaffert et al. 2005, Wepner and Militz 2005, Larsson and Simonson 1994, Epmeier et al. 2004, Krause 2006, Bollmus 2011, Donath 2006, Scholz et al. 2009).

This work aims to assess the marine borers resistance of chemically modified Portuguese pine. Special focus was given to the hardness imparted by the modification and the hardness of the unmodified wood species used for control purposes.

\section{MATERIALS AND METHODS}

Flawless specimens of Maritime pine species (Pinus pinaster Ait.) with $25 \cdot 75 \cdot 200 \mathrm{~mm}$ RTL according to EN 275 were used. All wood specimens have 2-3 mm annual ring width and they were extracted from the sapwood part of the stems to be full chemically modified. Four modification methods were investigated: 1.3-dimethylol 4.5-dihydroxy ethylene urea (DMDHEU), methylated methylol melamine (MMF), tetraethoxysilane (TEOS) and wax. Before the modification, wood specimens were dried for $24 \mathrm{~h}$ at $103{ }^{\circ} \mathrm{C}$ and then impregnated with different solutions. A full cell process with a vacuum step of $0,5 \mathrm{~h}$ and $2 \mathrm{~h}$ pressure step at 1,2 $\mathrm{MPa}$ was used.

Impregnations with aqueous solutions of DMDHEU supplied by BASF (Ludwigshafen, Germany) were performed in the following concentrations: $0,8 \mathrm{M}, 1,3 \mathrm{M}$ and $2,3 \mathrm{M}$ using $4 \%$ magnesium nitrate relative to the mass of DMDHEU of the solution as catalyst $\mathrm{Mg}\left(\mathrm{NO}_{3}\right)_{2}$.

In the MMF modification, the original resin/water solution had $75 \%$ of concentration. To obtain two levels of concentration, it was diluted with water. After impregnation, specimens were dried for $48 \mathrm{~h}$ at room temperature. For resin curing, wood material was stored four days in an oven. Five steps of temperature were used, with increasing $10^{\circ} \mathrm{C}$ every day until reach $90^{\circ} \mathrm{C}$. 
TEOS was applied in sol state as described by Donath et al. (2004). Ethanol (1 mol) was added to $1 \mathrm{~mol}$ and stirred at ambient temperature for $0,5 \mathrm{~h}$, where the maximum concentration was obtained (T2). Half weight of mass water was added to this solution to obtain lower concentration (T1). After the impregnation, specimens were cured in an oven at $60{ }^{\circ} \mathrm{C}$ for 4 days.

For wax modification, two types of wax were used, montan wax and amid wax. The wax was impregnated at temperature of $120^{\circ} \mathrm{C}$ in liquid state.

In addition, for comparative purposes, high natural resistant wood species (Ipê lapacho Tabebuia serratifolia) suggested by Longwood (1971) and Scheffer and Morrell (1998), European Beech (Fagus sylvatica) and Blue Gum (Eucalyptus globulus) were included in the experiment. According to EN275 (1992), specimens treated with acid copper arsenate CCA should be used too as comparative reference of biocide preservative. These specimens were extracted from two logs treated in autoclave with industrial scale with $15 \mathrm{~cm}$ in diameter and 1,5m long supplied by CARMO madeiras company (Lisboa, Portugal). In order to analyze the gradient of CCA chemical distribution on the cross-section, separated analyze was done. In the cross section of the log, three different depths were analyzed. Five wood pieces were extracted, with $5 \cdot 15 \cdot 25 \mathrm{~mm}$ RTL dimensions, milled and the powder was analyzed to determine the Copper and Chromium content.

Ten specimens per modification and control species were used, resulting in total of 170 specimens.

The arrangement in the open sea followed all suggestion of EN 275 standard. All wood specimens were mixed with unmodified wood experiment ran in parallel at the site, Porto, Portugal, $41^{\circ} 11^{\prime} \mathrm{N}$ $8^{\circ} 42^{\prime} \mathrm{W}$ (Lopes et al. 2013).

The exposure started in March 2009. Three inspections were made, after six months and then annually in the spring. At each inspection, fouling around the specimens was carefully removed with a scraper, visual inspected, $\mathrm{x}$-rayed and placed back in to the seawater.

The first inspection took place at October 2009; three specimens per modification and control species were inspected.

The second inspection was carried out in February 2010; 45 specimens in total ( 3 specimens per modification and level and 15 specimens of control pine species) were extracted, x-rayed and visually inspected. The low marine borers activity at the second inspection $\left(12^{\text {th }}\right.$ month, $1^{\text {st }}$ year $)$ postponed the $3^{\text {th }}$ inspection to the $24^{\text {th }}$ month instead of having the inspection at the 18 th month.

The third inspection was carried out in March 2011, where all material exposed was extracted, visually inspected, $\mathrm{x}$-rayed and placed back.

At the site, in the north of Portugal, the sea water has an annual average temperature of $11-12^{\circ} \mathrm{C}$ at five meters deep and $14-18.5^{\circ} \mathrm{C}$ on the surface (www.hidrografico.pt). Solids content of $35,5 \mathrm{~g} .1^{-1}$ and salinity of the 30 up to 32,5PSU were found in situ in August 2009.

The x-raying was performed in Centro Hospitalar de Vila Nova de Gaia - Espinho with fixed equipment Philips (Einthoven, Netherlands). Each specimen was X-rayed, pictured and rated according to the range presented in the EN 275 standard, for Teredinids and other molluscs and for Limnorids and other crustaceans.

The X-ray images were obtained and treated with Philips DiagNET 2.2 software (Einthoven, Netherlands). 
Fouling and boring organisms were extracted from the wood and identified under a stereo microscope in the Centre of Marine and Environmental Research of the Porto University (Porto, Portugal). Boring organisms were classified according to Turner (1966) and Schultz (1969).

The Brinell hardness was evaluated in radial direction according to the European standard EN 1534 using a universal Zwick/Roell Z010 testing machine (Ulm, Germany).

The Janka hardness test measured the required force to embed an $11,28 \mathrm{~mm}(0,444 \mathrm{in})$ steel ball into the material, modified or not, until the half ball's diameter was reached. The same universal Zwick/Roell Z010 testing machine (Ulm, Germany) was used.

For the statistical analysis, a computerized ORIGIN 13.0 software was used. The standard deviation through a rectangle, average (-), median (x), upper and lower whisker with 5 and 95 percentile for different analyses were presented for univariate analysis, see Figure 1. For comparative purposes, to verify whether a attack or variable was significant or not a t-test with a $95 \%$ confidence interval and level of significance at $\mathrm{p}<0,05$ were used.

\section{RESULTS}

Table 1 shows the density of specimens at $65 \%$ of relative humidity $(\mathrm{RH})$ and weight percent gain (WPG) for control un- and modified wood: DMDHEU, MMF, TEOS and wax (amid and montan wax).

Table 1. Density, WPG and abbreviations used for control pine and modified wood $(n=10)$.

\begin{tabular}{l|l|lll|ll|ll|ll}
\hline Modifications & 0 & D1 & D2 & D3 & i1 & i2 & T1 & T2 & WA WL \\
\hline Concentration & ctrl & \multicolumn{2}{l}{$\begin{array}{l}\text { DMDHEU } \\
\text { medium and high }\end{array}$} & $\begin{array}{l}\text { Melamine } \\
\text { low / high }\end{array}$ & $\begin{array}{l}\text { TEOS } \\
\text { low / high }\end{array}$ & $\begin{array}{l}\text { Amid } \\
\text { montan }\end{array}$ \\
\hline Density [kg.m $\left.{ }^{-3}\right]$ & 574 & 652 & 679 & 728 & 631 & 726 & 616 & 649 & 1063 & 1098 \\
WPG [\%] & --- & 9 & 18 & 34 & 9 & 24 & 13 & 32 & 112 & 110 \\
\hline
\end{tabular}

The solution concentration correlate with weight percent gain (WPG) acquired by the wood material. Before all impregnations, wood material was dried over $24 \mathrm{~h}$ at $103^{\circ} \mathrm{C}\left(\mathrm{W}_{\text {unmodified }}\right)$. After impregnations and curing, wood material was dried to access the dry weight $\left(\mathrm{W}_{\text {modified }}\right)$. The weight percent gain was obtained by the difference between both weight measurements for each type of modification methods.

All WPG found in this study were similar to reference WPG in the literature with Scots pine, respectively (Bolmus 2011, Krause 2006, Dontah 2004, Scholz et al. 2009).

Table 2 shows the density of control species at $20^{\circ} \mathrm{C}$ and RH of $65 \%$ : Ipê (Tabebuia serratifolia), Beech (Fagus sylvatica), Blue Gum (Eucalyptus globulus) and Maritime pine treated with CCA. 
Table 2. Density for control species, Beech, Ipê, Blue Gum and Maritime pine treated with CCA ( $\mathrm{n}=10)$.

\begin{tabular}{l|l|l|l|l}
\hline Assignment & CCA & E & B & P \\
\hline Species & Pine, ${ }^{(\mathrm{a})} 12 \mathrm{~kg} \cdot \mathrm{m}^{-3}$ & Blue & Beech & Ipê \\
& & Gum & & \\
Density $\left[\mathrm{kg} \cdot \mathrm{m}^{-3}\right]$ & 544 & 908 & 780 & 1018 \\
\hline
\end{tabular}

(a) Treatment with $1,75 \%$ CCA (mass/mass) showed sapwood retention of $12 \mathrm{~kg} \cdot \mathrm{m}^{-3}$.

For logs with $15 \mathrm{~cm}$ of diameter treated in industrial scale where control specimens treated with CCA were extracted, Table 3 shows the biocide gradient of CCA penetration in the log cross section.

The chemical content of copper at different depths has shown a gradient up to $52 \%$. However, Teredinids individuals did not show any preference behaviour by any part of the specimens. Whilst, the near part of the pith was preferred by Limnorids animals.

Table 3. Copper and Chromium content $\left(\mathrm{CuSO}_{4} 5 \mathrm{H}_{2} \mathrm{O}[35 \%], \mathrm{K}_{2} \mathrm{Cr}_{2} \mathrm{O}_{7}[45 \%], \mathrm{As}_{2} \mathrm{O}_{5} 2 \mathrm{H}_{2} \mathrm{O}[20 \%]\right)$.

\begin{tabular}{l|l|l|l|l}
\hline $\begin{array}{c}\text { Depth }^{(\mathrm{a})} \\
{[\mathrm{mm}]}\end{array}$ & $\begin{array}{c}\mathrm{Cu} \\
{\left[\mathrm{mg} \cdot \mathrm{g}^{-1}\right]}\end{array}$ & Gradient [\%] & $\begin{array}{c}\mathrm{Cr} \\
{\left[\mathrm{mg}^{-1} \mathrm{~g}^{-1}\right]}\end{array}$ & $\begin{array}{c}\text { Gradient } \\
{[\%]}\end{array}$ \\
\hline 11 & 6,4 & --- & 12,9 & --- \\
11 & 6,4 & --- & 13,5 & --- \\
\hline 22 & 4,8 & -25 & 10,4 & -19 \\
\hline 35 & 3,3 & -52 & 7,5 & -42 \\
35 & 3,3 & -52 & 7,7 & -40 \\
\hline \multicolumn{6}{r}{ (a) Depth, from the outer surface to the pith }
\end{tabular}

\section{Biofouling}

Fouling and organisms at each inspection were examined, compared and already presented in Lopes et al. (2013). Between un- or modified wood, material surface did not show any difference in the biofouling.

The activity of the both main marine borers, with surface galleries and tunnels inside the wood material (modified wood or not), will be herein after referred to as Limnorids and Teredinids attack according to EN 275 , respectively.

\section{Inspections}

After 6 months of sea exposition, the $1^{\text {st }}$ inspection was carried out. All wood specimens, modified or not, were already wrapped with biofouling. Only in the control Maritime pine slight or trace signs of attack were found. Small holes with 1.5 to $2 \mathrm{~mm}$ of diameter for incoming of Teredinids larvae were visible. In other species (Ipê, Beech, Blue Gum and CCA treated pine), types and levels of chemical modification, any hole or signs of attack were not detected.

After 12 months of sea exposition, the $2^{\text {nd }}$ inspection was carried out. No sign of attack was recorded in controls wood species (Ipê, Beech, Blue Gum and CCA treated pine) and modified wood with resin (DMDHEU and MMF). The control pine and lumen fill modifications (both concentrations of TEOS and amid wax) have shown slights or trace attacks of Limnorids (detected visually). The x-ray has shown only a small number of Teredinids in the control Pine. However, those organisms have presented large dimensions, $13 \mathrm{~mm}$ in diameter and $18 \mathrm{~cm}$ in length. 
After 24 months of exposition, the $3^{\text {rd }}$ inspection was carried out. Different ranges of attacks were found: Completely destroyed specimens of control pine and lumen fill modification (both concentrations of TEOS and both types of wax); up to slight or trace attack in the DMDHEU and MMF resin modifications with low concentrations. In the control hardwood species (Ipê) and modified wood with resin (medium and high concentrations, D2 and D3) no sign of attack were recorded.

Figure 1 shows on the left vertical axis the marine borers attacks, stand at $1^{\text {st }}$ and $2^{\text {nd }}$ year for control species and modified wood (on the horizontal axis) with associated WPG ( $\mathcal{H}$ ) on the right vertical axis.

It is noted at the end of the first year:

- $\quad$ No attack by Teredinids for all materials (except for pine control);

- $\quad$ Slight attack by Limnorids in pine control and lumen fill modification, TEOS and wax.

At the end of the second year, high activities of marine borers were found into undifferentiated control wood species and modified wood.
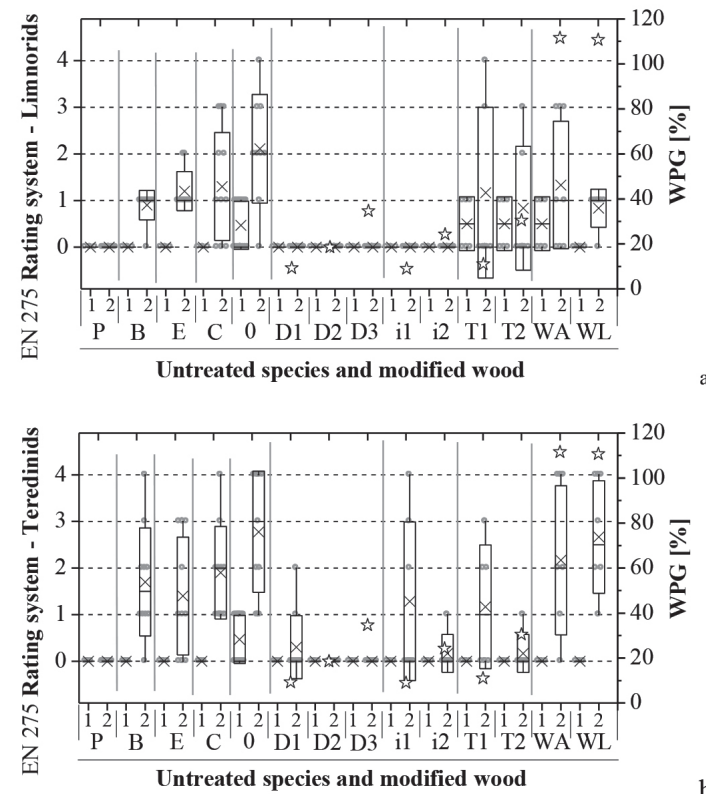

b

Figure 1. Marine borers activities: a) Limnorids and; b) Teredinids over the $1^{\text {st }}$ and $2^{\text {nd }}$ year of exposition. Rating according to EN 275 (0-no attack and 4-maximum severity of attack) for control species and modified Maritime pine (WPG is) tested in Leixões harbour $(n=9)$.

For abbreviations see Table 1 and Table 2. 
In the pine control the greatest attack (grade 3) was recorded by Teredinids. Whilst attack by Limnorids was also visible, but with moderate grade.

After two years of wood material exposition in open sea, some conclusions can be drawn:

- Pure sapwood pine, was completely destroyed.

- Ipê wood species did not suffer any attack by any marine borers.

- Beech wood suffered a severe attack by Teredinids and a slight attack by Limnorids.

- Maritime pine treated with $12 \mathrm{~kg} \cdot \mathrm{m}^{-3}$ of CCA has shown severe attack by Teredinids and Limnorids.

- Modified wood with resin, MMF and DMDHEU, regardless the level of modification, did not show any attack by Limnorids.

- DMDHEU resin with low concentration (D1, 9\%WPG) suffered a slight attack by Teredinids.

- DMDHEU resin with medium and high concentration (D2 and D3) did not show traces of attack by marine borers.

- MMF modified specimens with low and high concentrations have shown a severe and slight attack by Teredinids, respectively.

- MMF resin with 9\% of WPG (i1) has shown a slight attack in average, however, one specimen appeared completely destroyed by Teredinids.

- Modified specimens with low concentration of TEOS (15\% WPG, T1) exhibited a severe attack by Teredinids and total destruction by Limnorids.

- High concentration of TEOS ( $28 \%$ WPG, T2) has shown a slight attack by Teredinids with small individuals but in large number and a severe attack by Limnorids was recorded.

- Modified wood with wax has shown a severe attack by Teredinids and Limnorids organisms.

The highest degree of attack by Teredinids occurred in the control pine, Beech and Blue Gum species as well for wood modified with both types of wax. The attacks by Limnorids were more frequent than Teredinids in $6.5 \%$ of the 170 inspected specimens. In particular, modified wood with TEOS $(28 \%$ WPG, T2 high concentration) showed high Limnorids attack than Teredinids attack.

Figure 2 shows the x-ray of some modified specimens with WPG in percentage.

Specimens modified with TEOS have shown a large numbers of colonised Teredinids individuals, however it seems that they did not or had difficulties to grow inside of the wood material, see specimens T11 and T21 in Figure 2.

In the resin-based modification, DMDHEU or MMF, Teredinids individuals have grown normally, see specimen D14 and i17 in Figure 2. Then, tunnels with 13mm of diameter and 26cm in length were found.

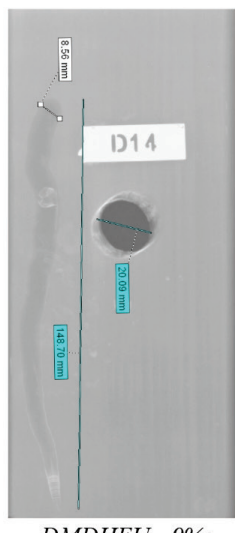

DMDHEU - 9\%;

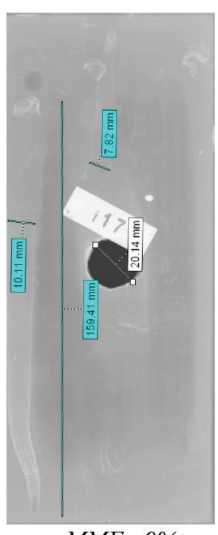

$M M F-9 \%$;

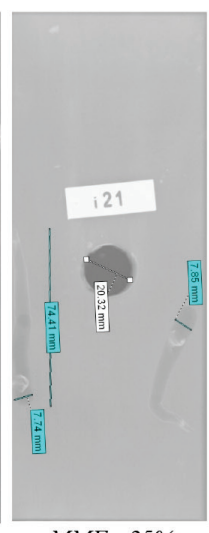

$M M F-25 \%$;

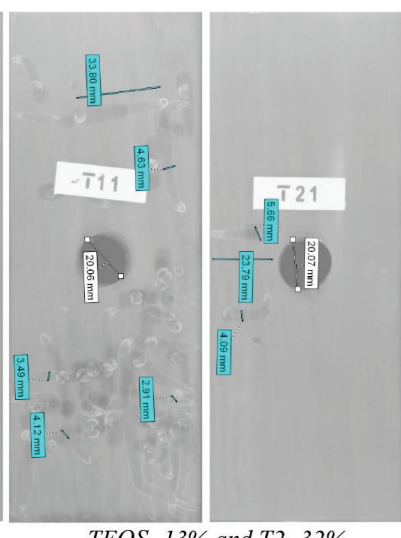

TEOS $-13 \%$ and $T 2-32 \%$

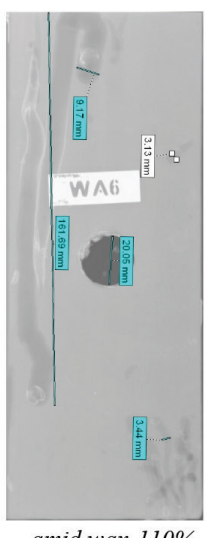

amid wax-110\%

Figure 2. X-ray of the activity of Teredinids after 2 years of exposition. 


\section{Hardness}

The main marine borers organisms (Teredinids and Limnorids) act in different ways. The former drilled tunnels inside the wood material affecting large area with undifferentiated choice of early- or late-wood. Teredo animal is the largest known xylophagous and usually makes tunnels with 5 up to $20 \mathrm{~mm}$ of diameter. The latter, Limnorids produced galleries at the surface of wood with preference in the early-wood. Limnoria animal has a few millimetres and makes tunnels preferentially in the surface softer early-wood of growth rings (Cragg et al. 2007).

The connection between hardness and marine borers activities (surface Brinell hardness and Limnoria action as well as the depth Janka hardness and Teredo action) seems to be a reasonable approach to access the contribution of hardness in to the marine borers resistance.

Figure 3 shows the hardness of specimens (in the left vertical axis) of control-unmodified species (Ipê, Beech, Blue Gum, CCA and unmodified wood pine) as well as modified wood (in the horizontal axis) with whisker box plot. Except the hardness of Ipê-P species all others (un- or modified species) are below the grey line in the middle of the picture. Also in the Figure 3 but on the right vertical axis, the attacks by marine borers were presented by circles above the horizontal grey line. For modified wood, the level of modification, or concentration solution associated to the WPG acquired for specimens, were shown in the vertical right axis through a five-pointed star.

The Brinell hardness (BH) has shown the following performances comparing each modification to control wood pine specimens:

- Specimens modified with DMDHEU resin increased the BH between 80 up to $140 \%$, for low and high concentration, respectively.

- Specimens modified with MMF resin increased the BH between 40 up to $60 \%$, for low and high concentration, respectively.

- Specimens modified with TEOS increased the BH between 30 up to $50 \%$, for low and high concentration, respectively.

- Specimens modified with wax increased the BH between 180 up to $210 \%$, for amid and montan wax, respectively (Figure 3a).

The Janka hardness $(\mathrm{JH})$ has shown the following performances comparing each modification to control wood pine specimens:

- Specimens modified with DMDHEU resin increased the JH 40 up to $75 \%$, for low and high concentration, respectively.

- Specimens modified with MMF resin increased the JH up to $50 \%$.

- Specimens modified with TEOS increased the JH up to $40 \%$.

- Specimens modified with both types of wax increased the JH up to $180 \%$.

Unmodified control species (Ipê, Beech and Blue Gum) have shown similar mean surface BH and JH found in the literature (Machado et al. 2003, Kretschmann 2010).

All un- or modified wood material decreased the JH in saturated conditions. In the modified wood with resin based and irrespective the level of modification, the soaked JH decreased by $25 \%$ for DMDHEU and up to $40 \%$ for MMF resin. In the lumen fill modification: Irrespective TEOS concentration, soaked $\mathrm{JH}$ decreased up to $45 \%$; Specimens modified with wax, the soaked JH decreased up to $30 \%$. Unmodified wood species have shown a varied reduction: up to $40 \%$ for control pine and Blue Gum; $30 \%$ for Beech and $10 \%$ for Ipê (Figure $3 b$ ). 
The increasing of hardness, on the surface $\mathrm{BH}$ and deeper $\mathrm{JH}$, matched a clear reduction of marine borers attack for unmodified wood species - Ipê, Beech, Blue Gum and Maritime pine (in the left part of the Figure $3 \mathrm{a}$ and $\mathrm{b}$ for Limnorids and Teredinids, respectively). However, the role of extractives was not taken in to account. Therefore, any conclusion about the contribution of hardness (as isolate variable) between different wood species to avoid the marine borers attack can be extract only by accident, at one hand.

On the other hand, lumen fill modification with wax has the explanation for the role of hardness on the marine resistance. The BH increasing on the surface (up to $210 \%$ ) resulted in a slight decrease attack by Limnorids (not significant).

In specimens modified in cell wall, irrespective the concentration or type of resin (DMDHEU or MMF), the attack of Limnorids was not recorded at any specimens.
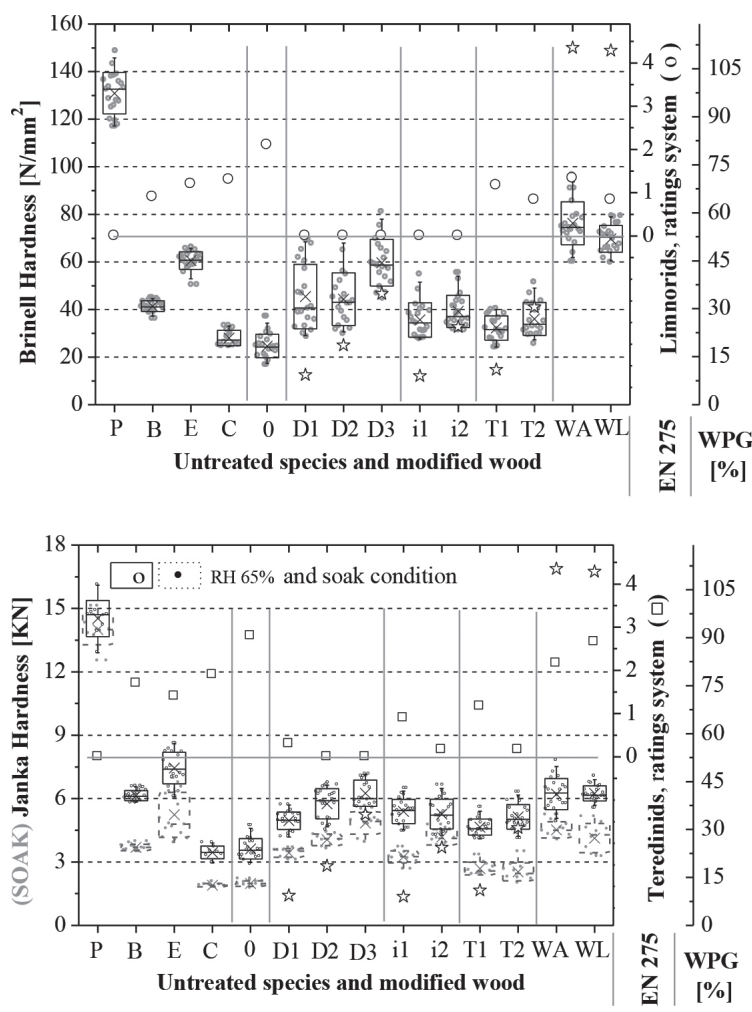

Figure 3. a) Brinell hardness and attack by Limnorids ( $\mathrm{O}$ ),

b) Janka hardness and attack by Teredinids ( $\square$ ), at $65 \%$ RH and soak conditions, and WPG $\dot{\text { 幺 }}(\mathrm{n}=10)$ of wood exposed in Leixões harbour, Portugal (0-no attack and 4-maximum severity of attack). 
The deeper $\mathrm{JH}$ and the activity of Teredinids supported the latter conclusion about the hardness effect in the Limnorids behaviour (Figure $3 a$ and $b$ ). In the wood specimens modified with both types of wax, the attack of Teredinids has shown no significant difference to unmodified pine, despite the JH increased up to $100 \%$. Whilst in unmodified wood species (Ipê, Beech, Blue Gum and pine), a decrease of JH matched an increasing of the attack by Teredinids, where the effect of extractives were not taken in to account. Specimens modified with wax showed higher hardness ( $\mathrm{BH}$ and $\mathrm{JH})$ and did not show any effect on marine bores resistance.

In the resin cell wall modification, hardness increasing matched a decrease of attack, from severe up to trace/slight attack, comparing un- to modified wood with low resin concentration (D1 and i1), respectively. For medium concentration of resin (DMDHEU and MMF, D2 and i2), conclusions cannot be drawn until fifth year of sea exposition be reached. But in this case, hardness has not played the main role rather than the toxicity of the resin embedded.

In the lumen fill modification: Irrespective the type of wax, hardness increasing did not affect the wood resistance to Teredinids attack; Specimens modified with TEOS have shown a proportional decreasing between the attack by Teredinids and the level of the modification. However, individuals length's, not the number, into the wood material seems to corroborate the abrasive role of silica material imparted by the modification. Over the time, modified wood with TEOS will not present sufficient resistance to marine borers (Teredinids or Limnorids), see also T11 and T21 specimens in Figure 2.

Cookson et al. (2007) conducted an experiment over long-term exposition in Australian seawater field. He did not find significant differences between CCA treated pine specimens, associated or not with 0,5 and $15 \%$ of silica content. The latter work together with this study, corroborate that the marine resistance was not attributable to the increasing of hardness by the TEOS modification (up to $20 \%$ see Figure 2 and Figure 3). The silica particles of the lumen fill material of TEOS may render the wood abrasive to the denticulate of bivalves and did not allow the organisms to grow up normally. Nevertheless, no effect was shown regarding to the resistance of crustaceans Limnorids activity.

\section{DISCUSSION}

In this study, results of the unmodified wood species (Ipê, Beech, Blue Gum and Maritime pine) were not a surprised at all. Similar results were found in literature in different environment conditions and timing (de Palma 1980, Beesley 1980, Gambetta and Orlandi 1980, Eaton and Hale 1983, Cookson et al. 1998, Brelid et al. 2000, Cookson and Scown 2003, Westin et al. 2004, Cookson et al. 2007). However, new site with different features, mainly water temperature and salinity, provided relevant data.

Modified wood with wax was used before to prevent leaching of biocide chemicals by MacLean (1959). He showed relative low effectiveness after long term exposition at Pensacola, FL USA in the Southern Yellow pine modified with paraffin, montan wax mixtures (with low retention 30\%) and creosote. In this study, specimens modified with wax have shown any resistance to marine borers, despite the high hardness presented. However, they help to clarify that; regardless the hardness of wood, its effect on marine bores resistance can be neglected.

Johnson and Rowell (1988) and Brelid et al. (2000) found some severe and trace attack by Limnorids and Terebrans and Shaeroma in acetylated wood exposed at various seawater sites. In the acetylated wood, the hardness increases up to 25\% (Larsson and Simomson 1994, Epmeier et al. 2004). The slight increase of hardness was not helped by the toxicity of the chemical to impart a better marine performance. 
In the modified wood, two main variables are associated: The toxicity of chemicals and the hardness. As isolated variable only the toxicity played an important role in the marine borers resistance. Borges et al. (2008) showed good predictions of the marine performance with DMDHEU and phosphobutane tricarboxylic acid PBTC with short-term lab test. Similar results to the latter study were shown with low level of DMDHEU resin in the field trials - Olhão, Algarve in Borges et al. (2005).

Krause (2006) has shown similar features of wood furfurylated and DMDHEU modified specimens. In the furfurylated wood with low concentration $(10 \% \mathrm{WPG})$ all specimens were severely attacked after 4 years of exposition in the North sea (Lande et al. 2004). Under similar condition but with medium level of modification (30\% WPG), DMDHEU modified specimens had a good performance over 7 years (Westin et al. 2007). That means, a minimum level of modification was required. Similar conclusion can be drawn for DMDHEU in this study. The low concentration of modified wood with DMDHEU resin has shown trace attack of Teredinids. Whilst, medium and high concentration of DMDHEU have shown no attack by Teredinids and Limnorids (D2 and D3).

For unmodified wood species density correlated with hardness and, in the same line, with performance of the marine borers, Teredinids and Limnorids respectively in Figure $3 a$ and $b$.

This work has shown the same tendency as Cragg et al. (2007) did in a laboratory assay with a large variety of wood species. They revealed good correlation between micro-hardness and faecal pellet production by Limnoria quadripunctata. Sivrikaya et al. (2008) found a minor correlation between density of Turkish woods and pellet production in a screening laboratory test for the same organism, Limnoria. Sen et al. (2008) reported that high natural resistance against to marine borers not depended on the hardness but more of the extractive contents of tropical hardwood (in field conditions, Mediterranean and Black sea). Similar conclusion can be drawn from this work. However, due to different amounts and type of extractives involved at different wood species and a minimum of five year to validate the behaviour of a single wood species, no special attention was given to the correlation between hardness and the decreasing of marine borers attack.

The type and amount of extractives varies tremendously within species of wood (Hill 2006). Extractives of Maritime pine are mainly compounds soluble in ethanol and water. The extractives content varies between 1,1 up to 3,0\% for sapwood and 2,6 up to $13 \%$ for heartwood (Esteves 2006). The extractives of Blue Gum are mainly water soluble $(2,1$ to $3,1 \%)$ and ethanol soluble compounds (1,8 up to 3,1\%) (Pereira and Miranda 1991 in Esteves 2006). In Beech, there are more extractives in sapwood $(3 \%)$ than in heartwood $(1,5 \%)$ (www.holzlexikon.de). Accidentally with unmodified wood species used in this study, the marine borers attacks correlated better with density (hardness) than with the amount of extractives (Figure $3 \mathrm{a}$ and $\mathrm{b}$ ).

\section{CONCLUSION}

This study was set up to get more information on several factors influencing the natural resistance to marine borers of different unmodified wood species and modified pine. Open sea field exposition was used.

Wood specimens were strongly attacked by the common shipworm Teredo navalis and Lyrodus pedicellatus (Teredinidae) and moderate by crustacean borers Limnoria tripunctata Menzies and Limnoria quadripunctata Holthuis (Limnoridae).

Over two years of exposition in the temperate waters, modified wood with thermosetting resins has shown the best performance against marine borers, Limnorids and Teredinids. For low level of modification slight/trace attack was recorded by Teredinids and minimum WPG seems to be required to be effective against to Teredinds. The cell wall modification was effective against to Limnorids, without any attack recorded in the DMDHEU and MMF resins. 
Lumen fill modification did not affect the marine-borers performances despite the significant increasing of the classical hardness provided for both type of wax (amid and montan wax). TEOS modification did not reduce the number of infections by boring organisms on the surface and into the wood, but their growths in the inner wood parts were delayed.

The local hardwood species, Blue Gum Eucalyptus globulus, did not give satisfactory performance.

Hardness did not play the main role in the marine resistance as the chemicals toxicity does. For unmodified wood species, the marine resistance need to contemplate the amounts and type of extractives of wood species.

\section{ACKNOWLEDGMENTS}

Authors wish to thank: APDL administration of Leixões Harbour for providing the sea space to expose the wood material; The Radiology department of Vila Nova de Gaia Hospital for providing the x-ray; Dra. F. Russell Pinto from the Centre of Marine and Environmental Research of the Oporto University for identifying the biofouling and marine borers; as well as Dra. Júlia Carmo (www.carmo.pt, Lisboa, Portugal) for providing CCA treated logs.

\section{REFERENCES}

Beesley, J. 1980. IRG / COIPM International marine test, Progress Report 6 - Report of third inspection (1 year) in Australia. International Research Group on Wood Preservation, Document 80456, Raleigh, NC, USA.

Behr, EA.; Behr, CT.; Wilson, LF. 1972. Influence of wood hardness on feeding by eastern subterranean termite, Reticulitermes flavipes (Isoptera, Rhinotermitidae). Annals of the Entomological Society of America 65(2): 457-460.

Bollmus, S. 2011. Biologische und Technologische Eigenschaften von Buchenholz nach einer Modifizierung mit 1,3-dimethylol-4,5-dihydroxyethyleneurea (DMDHEU). PhD Dissertation GeorgAugust-Universitat Goettingen, Germany, ISBN 978-3-86955-953-6 (in German).

Borges, LMS.; Cragg, S. 2005. Laboratory and field tests of anti-marine borer potential of wood modified with dimethyloldihydroxyethylenurea (DMDHEU) and phosphobutane tricarboxylic acid (PBTC). In: Militz, H.; Hill, C. (Hg): Wood modification: Processes, properties and commercialisation. The second European Conference on Wood Modification ECWM, Göttingen, Germany: 198-201.

Borges, LMS.; Cragg, SM.; Bergot, J .; Williams, JR. ; Shayler, B. ; Sawyer, GS. 2008. Laboratory screening of tropical hardwoods for natural resistance to the marine borer Limnoria quadripunctata: The role of leachable and non-leachable factors. Holzforschung 62(1): 99-111.

Brelid, PL.; Simonson, R.; Bergman, O.; Nilsson, T. 2000. Resistance of acetylated wood to biological degradation. Holz als Roh-und Werkstoff 58(5): 331-337.

Cookson, LJ.; Mcintyre, CR.; Scom, DK. 1998. Laboratory aquaria evaluation of CDDC (copper dimethyl dithio carbamate) against marine borers. The International Research Group on Wood Preservation, Document 98-10262, Maastricht, The Netherlands. 
Cookson, LJ.; Scown, DK. 2003. Ten Year Marine Borer Exposure Trial of Chlorothalonil and Emulsified Preservatives in Australia. International Research Group on Wood Preservation, Document 03-30314, Brisbane, Australia.

Cookson, LJ.; Scown, DK.; McCarthy, KJ.; Chew, N. 2007. The effectiveness of silica treatments against wood-boring invertebrates. Holzforschung 61(3): 326-332.

Cragg, SM.; Danjon, C.; Mansfield-Williams, HD. 2007. Contribution of hardness to the natural resistance of a range of wood species to attack by the marine borer Limnoria. Holzforschung 61(2): 201-206.

De Palma, J. 1980. Co-operative trials to investigate the effect of timber substrate on the effectiveness of water-borne preservatives - panama test site results. International Research Group on Wood Preservation, Document 80-458, Raleigh, NC, USA.

Donath, S.; Militz, H.; Mai, C. 2004. Wood modification with alkoxys. Wood Science and Technology 38(7): 555-566.

Donath, S.; Militz, H.; Mai, C. 2006. Creating water-repellent effects on wood by treatment with silanes. Holzforschung 60(1): 40-46.

Eaton, RA.; Hale, MDC. 1983. Wood: Decay, Pest and Protection. Chapman \& Hall, London.

Eaton, R.; Ampong, F.; Barnacle, J.; Beesley, J.; Bultman, D.; Cookson, L.; Cragg, SM.; Depalma, J.; Gambetta, A.; Henningsson, B.; Levi, M.; Levy, C.; Nilsson, T.; Orlandi, E. 1989. An international collaborative marine trial to investigate the effect of timber substrate on the efficacy of CCA and CCB wood preservatives. Material and Organism 24(1): 51-79.

EN 275. 1992. Wood preservatives. Determination of the protective effectiveness against marine borers. European Standard, Bruxelles.

EN 335-2. 1994. Durabilidade da madeira e de produtos derivados - Definição das classes de risco de ataque biológico, Parte 2: Aplicação à madeira maciça. European Standard, Bruxelles.

EN 350-1. 1994. Durability of wood and wood based products - natural durability of solid wood. Part 1. Guide to the principles of testing and classi4cation of the natural durability of wood. European Standard, Bruxelles.

EN 350-2. 1994. Durability of wood and wood based products - natural durability of solid wood. Part 2. Guide to natural durability and treatability of selected wood species of importance in Europe. European Standard, Bruxelles.

EN 460. 1994. Durability of wood and wood based products - natural durability of solid wood. Guide to the durability requirements for wood to be used in hazard classes. European Standard, Bruxelles.

EN 1534. 2000. Wood and parquet flooring - determination of resistance to indentation (Brinell) test method. European Standard, Bruxelles.

Epmeier, H,; Westin, M.; Rapp, A. 2004. Differently Modified Wood: Comparison of Some Selected Properties. Scandinavian Journal of Forest Research 19(5): 31-37. 
Esteves, BMML. 2006. Melhoramento tecnológico por modificação térmica de madeiras Portuguesas. Phd Dissertation, Universidade Técnica de Lisboa, I.S. Agronomia, Lisboa, Portugal (in Portuguese).

Esteves, B.; Nunes, L.; Pereira, H. 2009. Furfurylation of Pinus pinaster Wood. In: Englund F, Hill CAS, Militz H, Segerholm BK (Hg.) The Fourth European Conference on Wood Modification. $4^{\text {th }}$ European Conference on Wood Modification, Stockholm, Sweden 415-418.

Fougerousse, M. 1971. Natural resistance of tropical timbers to attack by marine wood boring organisms. In: Jones, E.B.G., Eltringham, S.K. (Eds.), Marine borers, fungi and fouling organisms. OECD, Paris.

Gambetta, A.; Orlandi, E. 1980. IRG / COIPM International Marine Test, Progress Report 9 - Report of third inspection (2 years) in Italy. International Research Group on Wood Preservation, Document 80-461, Raleigh, NC, USA.

Green, M.; Mansfield-Williams, HD.; Pitman, AJ. 2004. Reduced hardness as an indicator of susceptibility of timbers to attack by Euophryum confine Broun. International Biodeterioration \& Biodegradation 53(1): 33-36.

Hill, C. 2006. Wood modification. Chemical, thermal and other processes. John Wiley \& Sons Ltd., Chichester, 239p.

Johnson, BR.; Rowell, RM. 1988. Resistance of chemically-modified wood to marine borers. Material und Organismen 23(2): 147-156.

Klüppel, A.; Militz, H.; Cragg, S.; Mai, C. 2010. Resistance of Modified Wood to Marine Borers. In: Hill CAS, Militz H, Andersons B (Hg.) The Fifth European Conference on Wood Modification ECWM5 Proceedings. $5^{\text {th }}$ European Conference on Wood Modification, Riga, 389-396.

Kollmann, FFP.; Côté, WA. 1967. Principles of wood Science and Thechnology In solid Wood. TitleNo. 1301 by Springer Verlag, Berlin Hieldelberg, Library of congress catalog card Number 67-29164.

Krause, A. 2006. Holzmodifizierung mit N-Methylolvernetzern. PhD dissertation, Georg-AugustUniversitat Goettingen, Germany (in German).

Krause, A.; Jones, D.; van der Zee, M.; Militz, H. 2003. Interlace treatment - Wood modification with N-methylol compounds, 1st European conference on wood modification, (pp.317-327). Ghent, Belgium.

Kretschmann, DE. 2010. Mechanical Properties of Wood. In. Wood Handbook. General Technical Report FPL-GTR-190. Madison, WI: U.S. Department of Agriculture, Forest Products Laboratory: 1-46.

Lande, S.; Westin, M.; Schneider, M. 2004. Properties of furfurylated wood. Scandinavian Journal Forest Research 19(5): 22-30.

Larsson, P.; Simonson, R. 1994. A study of strength, hardness and deformation of acetylated Scandinavian softwoods. Holz als Roh-und Werkstoff 52(2): 83-86.

Li, G.; Nicholas, DD.; Schultz, T P. 2008. Measurement of wood decay by dynamic MOE in an accelerated soil contact test. International Research Group on Wood Preservation, Document 08-20390, Istanbul, Türkei. 
Longwood, FR. 1971. Present and potential commercial timbers of the Caribbean. Northeastern Forest Experiment Station, Forest Service; formerly at the Tropical Forest Research Center of the Forest Service in Puerto Rico. Agriculture Handbook No. 207 O: 426-331 Forest Service, March.

Lopes, DB.; Mai, C.; Militz, H. 2013. Effect of hardness and size sample on marine borer resistance of untreated pine. Unpublished manuscript.

Machado, JS.; Costa, D.; Cruz, H. 2003. Evaluation of Pine timber strength by drilling and ultrasonic testing. International Symposium (NDT-CE 2003) Non-Destructive Testing in Civil Engineering 2003, (in Portuguese) [consulted 04-2007] [on line]<http://www.ndt.net/article/ndtce03/papers/p047/p047.htm>.

Maclean, JD. 1959. Results of experiments on the effectiveness of various preservatives in protecting wood against marine-borer attack. Report $\mathrm{n}^{\circ} .1773$ Forest Products Laboratory [on line] $<\mathrm{http}: / \mathrm{hdl}$. handle.net/1957/1959> [consulted 06-2010].

Morales-Ramos, JA.; Rojas, MG. 2005. Wood consumption rates of Coptotermes formosanus (Isoptera: Rhinotermitidae): a three-year study using groups of workers and soldiers. Sociobiology 45(3): 707-719.

Papadopoulos, AN.; Duquesnoy, P.; Cragg, SM.; Pitman, AJ. 2008. The resistance of wood modified with linear chain carboxylic acid anhydrides to attack by the marine wood borer Limnoria quadripunctata Holthius. International Biodeterioration \& Biodegradation 61(2): 199-202.

Schaffert, S.; Krause, A.; Militz, H. 2005. Up-scaling and process development for wood modification with N-methylol Compounds using superheated steam. In: Militz, H.; Hill, C. (Hg): Wood modification: Processes, properties and commercialisation. The $2^{\text {nd }}$ European Conference on Wood Modification ECWM. Göttingen, 161-168.

Scheffer, TC.; Morrell, JJ. 1998. Natural durability of wood: A worldwide checklist of species. Forest Research Laboratory, Oregon State University. Research Contribution 22. 58p., November.

Scholz, G.; Krause, A.; Militz, H. 2009. Capillary Water Uptake and Mechanical Properties of Wax Soaked Scots Pine. In: Englund F, Hill CAS, Militz H, Segerholm BK (Hg.) The Fourth European Conference on Wood Modification, (pp.209-212). Stockholm.

Schultz, GA. 1969. How to know the marine Isopod Crustaceans. William c. Brown Company Publishers, Iowa, 359p.

Sen, S.; Sivrikaya, H.; Yalçin, M. 2008. Natural durability of some heartwood from European and tropical African trees against marine organisms. International Research Group on Wood Protection, Document 09-10682, Istanbul, Turkey.

Sivrikaya, H.; Cragg, SM.; Borges, LMS. 2008. Variation of commercial timbers from Turkey in resistance to marine borers as assessed by marine trial and laboratory screening. International Research Group on Wood Preservation, Document 08-10668, Istanbul, Türkei.

Turner, R. 1966. A survey and illustrated catalogue of the Teredinids (Mollusca: Bivalvia). Museum of Comparative Zoology, Harvard University, Cambridge, Mass. 265p. 
Wepner, F.; Militz, H. 2005. Fungal resistance, dimensional stability and accelerated weathering performance of N-Methylol treated veneers of Fagus sylvatica. In: Militz, H.; Hill, C. (Hg): Wood modification: Processes, properties and commercialisation. The $2^{\text {nd }}$ Conference of Wood Modification ECWM, Göttingen, 169-177.

Westin, M.; Lande, S.; Schneider, M. 2004. Wood furfurylation process and properties of furfurylated wood. International Research Group on Wood Preservation, Document 07-40289, Ljubljana, Slovenia.

Westin, M.; Rapp, A.; Nilsson, T. 2006. Field test of resistance of modified wood to marine borers. Journal Wood Material Science and Engineering 1(1): 34-38.

Westin, M.; Rapp, AO.; Nilsson, T. 2007. Marine borer resistance of modified wood - Results from seven years in field. International Research Group on Wood Preservation, Document 07-40378, Jackson Lake Lodge, Wyoming, USA. 